\title{
The Intercultural Potentials of Intangible Cultural Heritage in Korea: Existentializing Experience and Creative Economy
}

\author{
SNJEŽANA ZORIĆ and KIM SANG HUN \\ Hankuk University of Foreign Studies, Seoul
}

\begin{abstract}
In this paper we want to thematize intangible cultural heritage under the aspects of its protection and representative function in promoting Korean culture around the world. We are further interested in its implementation within the newly promoted concept of creative economy aiming at the self-sustainability of the Korean economy and the creation of new jobs. Korean heritage is seen as a pragmatic tool for the realization of this goal, offering various cultural experiences to the tourists looking for authentic existential experiences, or to Koreans who are willing to learn their own culture anew. In addition, in the intercultural domains, where various encounters between Korean and Western artists are taking place, we are witnessing diverse con-creative processes leading to new artistic and cultural forms that are more attractive to the young Korean audience, lacking immediate experience of the old Korean tradition. We substantiate our thesis through several examples of small case studies in Buddhist temples, the Confucian Academy, Seoul Intangible Cultural Heritage Center and on the Nori Madang performance ground.
\end{abstract}

Key words: ICH, interculturality, authenticity, experience, creative economy

In a recent interview that was aired on the Korean Arirang TV network, ${ }^{1} \mathrm{Kim}$ Hye-in, ${ }^{2}$ chief researcher of the Korea Culture and Tourism Institute (KCTI) spoke about the culture and art trends in a project called Korea Culture and Art 2014. Based on the concept of national cultural heritage, the discussion on related research in the Institute revolved around various fields such as culture, art, economy and politics, looking for possibilities of creating cul-

\footnotetext{
${ }^{1}$ After 10 programme, on 12 th of January 2014.

${ }^{2}$ Through the text we are using Revised Romanization of Korean script Hangeul, in use since 2000. However, both transliterations - McCune Reischauer (1984-2000) and Revised Romanisation - are appearing in the text according to References cited and transliteration of proper names that do not necessarily follow any of suggested rules of both systems.
} 
tural products based on heritage, which would attract tourists to visit the country. It is emphasized in most governmental programmes that culture represents the most valuable asset, which is why more attention should be paid to mutual cultural enrichment between one's own and other cultures through various means of communication within the global world. Applying the "trans-research method", ${ }^{3}$ Korean academics from various fields are searching and digging for heritage in local areas for the sake of giving impetus to creative undertakings, which will enable creating new jobs and self-sustaining economic strategies in the country. In this regard, special focus is laid on tangible and intangible cultural heritage as a means of raising attention to the culture and art of local people, and looking for economic profit by drawing the interest of travellers towards Korea.

This (re)orientation in conceptualizing Korean intangible cultural heritage (hereinafter referred to as: ICH) is the consequence of the intensified presence of Korea on the world-scene, resulting in an increased concern about its self-presentation. However, also equally important is the fact that many Koreans do not seem to have any in-depth knowledge of their own tradition; they are lacking a frame of context for perpetuating tradition in everyday life. Thus, heritage is something with which Koreans themselves should become familiar.

In this paper we want to present brief outlines of the conceptual and practical changes in functions and meanings of ICH in Korea, since the awareness of its protection and preservation came along with the inception of folkloristics at the beginning of the 1960s. At that time, the Korean government was deeply aware of the urgency of safeguarding traditional cultural heritage. They put a great amount of effort into achieving this goal, utilizing both heritage and folkloristic sentiments in order to reinforce nationalistic ideologies and to (re)create Korean identity after the traumatic experiences under Japanese colonization (1910-1945) and during the Korean War (1950-1953). Throughout various historical periods and ruling regimes, Korean heritage underwent various implementations from outside of its genuine living context and kept changing until it eventually became an attractive item for tourists, who were in search of authenticity in existentializing intercultural experiences outside of their own life-world. The concept of existential authenticity was proposed by Wang in his attempt to clarify the meaning of the concept within philosophical and political discourse, and to develop it further searching for its relevance within discussions about tourist experiences. "In common sense terms, existential authenticity denotes a special state of Being in which one is true to oneself, and acts as a counterdose to the loss of 'true self' in public roles and public spheres in

${ }^{3}$ This term was not further elaborated on in the interview. 
modern Western society" (Wang 1999: 358). He characterizes the ideal of authenticity by either nostalgia or romanticism, because they idealize innocent and spontaneous forms of life in opposition to the self-constraints imposed by reason and rationality in modernity, and defines it further: "A sense of 'authentic self' involves a balance between two parts of one's Being: reason and emotion, self-constraint and spontaneity, Logos and Eros" (ibid.: 360). Analytically, Wang sees the possibility of twofold division of existential authenticity into intra-personal authenticity, which involves "bodily" feelings (ibid.: 361), and inter-personal authenticity, which is realized in encountering the Other (ibid.: 363-364). In this paper we suggest enlarging Wang's conceptualization by applying it in the domain of intercultural encounters as well. In other words, we argue that the phenomenon of intercultural embodiment of elements or whole life structures, such as Buddhism or martial arts that originate from foreign cultures, is evident among Western people trying to compensate their feeling of alienation within their own culture. Looking for solutions to escape a certain lack of meaning in their everyday life routines, it seems that the concept of existential authenticity, as suggested by Wang, bears theoretical potential to explain this need.

In an attempt to discern the complexity of our topic, ${ }^{4}$ we will take into consideration insights from various disciplines: from anthropology, folkloristics and tourist studies to the phenomenological and hermeneutical understanding of interculturality and its realization. Therefore, the methodology we advocate is less a clear-cut position but, as a phenomenon of interculturality itself, is moving "in-between" the disciplines and running into contradictions, especially when it comes to subjective experiences of authenticity of one's own or the alien life-world.

In her theorizing of ICH, Kearney (2009: 211) suggests the use of a phenomenological approach and argues that

the ultimate intangible is human consciousness, or what some cosmologies define as the human soul, the very substance of psychological engagements with human "being", the most intriguing, yet unimaginable aspect of the human condition. [...] The consciousness that surrounds this creates the parameters of cultural identity and heritage, yet carries the legacy of intangible slipperiness, and indescribability. It is perceived, at its best, to be ethereal, evanescent, and essential, but at its worst; abstract, elusive and vague. Most commonly deemed as that which cannot be seen or perceived through the senses, intangible cultural elements are often defined through their incorporeality. In phenomenological terms, this separation cannot exist.

\footnotetext{
${ }^{4}$ It includes ICH within and without its original context and its "authenticity", cultural memory as its repository, urgency to transmit and to teach heritage, transfiguration of folk heritage into high artistic forms, and reception of heritage and processes of generating authentic subjective experiences within intercultural encounters as a means of existentializing experience.
} 
We agree with the inseparability of both and suggest the term of embodiment in this context as a conscious effort to transform corporeal awareness and continue the phenomenological procedure, reflecting the experience of "in-between" that comes into being through permeation of corporeal and incorporeal, and traditional and newly created artistic forms, cognition and feelings.

After setting the scene with descriptions of endeavours, which have been undertaken to preserve important Korean intangible heritage Uungyo Muhyeong Munhwajae) since the Third Republic, ${ }^{5}$ we want to present small case studies related to preservation and transmission of heritage in the context of Buddhist temples (Beongwonsa and Geumseonsa), the Confucian Academy (Sosuseowon), the Seoul Nori Madang performance-ground and the Seoul Intangible Cultural Heritage Center (Gyoyukjeonsijang). They all share common aims - apart from safeguarding Korean traditional culture and arts, and in their transmission in regular performances they offer knowledge of and experience in them in various educational courses and trainings. In that sense they have the potential to become places of encounter and interaction among Koreans as well as "between" Korean culture and the cultures of the tourists visiting those places and looking for authentic existential experiences (cf. Steiner and Reisinger 2006). Our interest also lies in the hermeneuticial potential of the concept of "eventness" of the encounter "in-between" within various cognitive frames and local epistemologies. This happens at the moment of opening up the ground for a new beginning wherein the longing for something absent may be realized in the presence of corporeal awareness of the Other and oneself. ${ }^{6}$

Authenticity as it is thematized nowadays in the academic discourse on tourism and the culture industry, is a very ambiguous concept, while each attempt to define it seems to lead us onto even more slippery ground in the space of "in-between". We could additionally characterize it, according to Vincent Crapanzano, as the "'analytical Third' - a structure structuring our interactions" (Davies 2010: 21). The question with subjective concepts such as these is, how can we reach a common discoursive platform within the discussion of commercial utilization of cultural heritage.

${ }^{5}$ This is the period from 1963 to 1972 under President Park Chung-hee. During his rule, the Charter of National Education was adopted and four main goals were formulated: national revitalization, creating self-reliant individuals, promulgating a new co-operative image of the nation and supporting anticommunism (Yang, S. Ch. 1999: 757).

${ }^{6}$ Or, as Köhler (2001: 101) put it, it is "das Ereignis des selbstvergessenen Ineinander zweier Menschen, die sich für diesen Augenblick zurückwenden zu den Anfängen ihrer körperhaften Existenz". 
Snježana Zorić and Kim Sang Hun, The Intercultural Potentials of Intangible... NU 51/1, 2014, pp 155-181

\section{BEGINNINGS}

In Korea, the concern about tangible and intangible heritage dates back to the time of Japanese colonization when the first list of cultural treasures was created under the name of "The Act of Treasures of the Joseon dynasty". The hard times of cultural cleansing that Korea had experienced under the Japanese administration led to many cultural phenomena being "forgotten", due to imposed prohibitions of expressing Koreanness in any shape or form. However, the policy of assimilation forced upon the nation by Japanese governors created the exact opposite effects. Koreans insisted on their distinctiveness from the Japanese, while feelings of patriotism grew together with nationalistic sentiments against the colonizer. Patriotism and nationalism were the basic emotions that accompanied the initial Korean efforts to protect, preserve and conserve their cultural heritage after the Japanese colonization and the Korean War. They remained the main inspiration of Korean national pride within the country's local politics, as well as in the attempt to present and represent itself to the foreign gaze in the course of growing globalization tendencies occurring after the Seoul Summer Olympic Games in 1988.

Looking back at the times after the Japanese colonization and the Korean War, the military regime of Park Chung-hee was very conscious of the fact that industrialization and modernization would cause rural cultural traditions to gradually die out. On the other hand, certain changes were mandatory in order to rebuild the country, which was devastated and suffering from poverty. With the abandonment of farming and agriculture, customs and rituals that had accompanied them started to disappear from everyday life. In light of these social changes, the Cultural Properties Administration proclaimed the Cultural Property Protection Law (CPPL; Munhwajae Bohobeob) in the year $1962 .{ }^{8}$ Explaining its purpose, Article 1 purports that the law "strive[s] for the cultural progress of the Korean people, as well as [to] contribute to the development of human culture by preserving cultural properties and their utilization" (Yang, J. 2003: 119). This "general development of human culture" could be understood as an anticipation of future intercultural encounters through which cultures would enrich each other, while their own unique cultural forms remain preserved.

\footnotetext{
${ }^{7}$ It was initiated by the Governor-General of Korea, Jirō Minami, in 1938. During his rule, the colonial policy toward Korea was very strict: he allowed only one newspaper in the Korean language to be published and introduced sōshi-kaimei, which implied changing all Korean names into Japanese.

8 This law was strongly influenced by the Law for the Protection of Cultural Properties (bunkazaihogohō), established in Japan in 1950.
} 
Later, the Cultural Properties Administration was re-named as the Cultural Heritage Administration (CHA; Munhwajaecheong). In 1999, it became a sub-ministerial agency with its headquarters in Daejon.

\section{FIRST FOLKLORISTS AND VARIOUS CONCEPTUALIZATIONS OF ICH}

The first efforts to collect Korean folklore were deeply connected with nationalistic motivations similar to that of Japanese and Chinese folklorists. As the process of Korea's Japanization was very strong and, through it, the annihilation of Korean identity, "alarmed at the rapid disappearance of traditional folk culture, folklorists and ethnologists urged the government to take action before it was too late" (Heyman 2011: 4). Kim Ŭn-t'ae (1986) described how the Japanese government especially banned shamanic practices (see in Yang, J. 2003: 17), which would later become a controversial issue as to whether they represented a genuine element of Korean identity or should rather to be seen as superstitious and backwardly religious forms that would better be extinguished if the country was to make progress on its path of modernization. Various discrepancies came into existence regarding the self-understanding and self-determination of Koreans at that time. "Most people regarded folklore as inferior to the high arts of the social elite, considering it somewhat childish and not worth preserving. [...] many people advocated its destruction rather than its preservation. Consequently, no-one wished to learn folk arts, and their disappearance seemed an inevitable cultural development" (Yim 2004: 11). ${ }^{9}$

But already in the 1960s, voices were being raised by enthusiastic individuals who argued that not only tangible treasures were worth preserving but also the lore of shamans, which had continuously been vanishing due to President Park Chung-hee's prohibitions and modern industrializing movements. Ye Yong-hae was one of those enthusiasts who, as a young reporter for the culture section in Hankook Ilbo, started to travel around the country, collecting traditional knowledge and skills, as well as shamanic practices, from various people he met (Soul 2012: 22). The outcome of his field-trips was the term "living human treasures", which he himself coined..$^{10} \mathrm{He}$ found more than fifty living human treasures who, according to Park's ideology, were fated to be "wipe[d] out [as] old evils" (ibid.). Deeply moved by their

\footnotetext{
${ }^{9}$ We can observe later how these folklore forms started to play a subversive role in student antigovernment demonstrations in the 1980s.

${ }^{10}$ This term was equivalent to the term "intangible cultural property" used in the Korean Cultural Property Protection Law.
} 
sad and tragic life-stories, Ye decided to tell their tales and publish them in a book called Living Human Treasures (1963). As described by Soul, the book "was published as a hardcover volume with a lining of the hemp cloth that Koreans use to make mourning garments. This was symbolic: the book was a shocking report on Korean traditional culture, which was in danger of disappearing with no recourse, and an eulogy written in advance" (ibid.: 23). Ye later became a member of the Cultural Heritage Committee and most of the "treasures" he found in the field were officially designated as intangible cultural heritage (ibid.). ${ }^{11}$

These "salvage undertakings" paralleled the development of Korean folkloristics associated with the names Song Sok-ha and Yim Suk-jay ${ }^{12}$ (Yang, J. 1994: 28). According to Michael E. Robinson (Cultural Nationalism in Colonial Korea, 1920-1925, 1988), both of them were very nationalistically oriented, like most intellectuals of their time who also took part in the Korean Independence Movement (ibid.). Nevertheless, there was a substantial difference between folklorists and the sirhak intellectuals. While the latter were focused on replacing Japanese cultural influences with Western paradigms that would contribute to building a new and modern society, the former concentrated on collecting cultural items from the past that were characteristic of Korean identity before the arrival of both Japanese and Western influences. Song and Yim saw the urgent necessity to record and salvage intangible cultural properties such as drama, dance, and music, which were still alive in some performances on certain occasions in Korean everyday life. Nevertheless, as the Korean society rapidly changed, and the traditional life-world faded preventing at least some parts of that life-world from vanishing into oblivion became the major concern of the folklorists. Yim Dawnhee, ${ }^{13}$ the daughter of Professor Yim remembers:

My father took up smoking at the age of 60 just so he could get closer to these people. And he would go around calling them "teacher". They were deeply moved that a Seoul National University professor would call them teacher. And yet even after he had finally convinced them of the urgent need to pass on their art form to future generations, they would often not show up for recording appointments [...] They were most concerned about the discrimination their children would likely suffer if their social status as traditional entertainers became public knowledge. But after their arts were designated as intangible cultural heritage, which meant official state recognition, they even came to be known as "new aristocrats". (Soul 2012: 23)

11 The first "important intangible cultural properties" designated in 1964 were Jongmyo Jeryeak, the ritual music performed yearly at the royal ancestral shrine of the Joseon dynasty, the Yangju mask dance drama (Yangju Byeolsandae Nori) and the clown's performance (Namsadang Nori) (ibid.).

${ }^{12}$ Also transliterated as Im Seok-jae.

${ }^{13}$ Also transliterated as Im Don-hui. 
Many of them started to appear on various television programs and are now called the icons of Korean culture. Nowadays, these icons represent the highest form of Korean intangible cultural heritage, they safeguard their treasures and transmit them to their students, keeping alive representative parts of Korean ancient traditions worthy of being shown to themselves and to others. Chosen living treasure has the privilege of providing spectators with an insight into the archives of cultural memories embodied in their knowledge and skills. "In this way, the living human treasures were encouraged to preserve their skills and arts" (Yim Dawnhee in Soul 2012: 23-24). The fact that the selection of an item to become intangible cultural heritage as well as the designation of their performers was recognized by the government, which led to a change of their social status, this created competition between performers and led to the "invention of tradition".

Song Sok-ha was not very much concerned about the theory and method of his work at the time (Yang, J. 2003: 21) as his duty was to do something against the Japanese "killing his nation's traditions" (ibid.: 31). Song, according to Yang Jongsung (2003: 23), opined how "performing arts would be an easy and popular tool for the cultural movement to use. He reasoned they were representative of Korean tradition and as such were an effective means of rejecting non-Korean cultures". Apart from preserving traditional cultural heritage, we can also add to the list of his merits the establishment of the Korean Folklore Society (Joseon Minsokhakhoe) and the first National Ethnological Museum of Korea (Gungnip Minjok Bangmulgwan). It is remarkable that Song was already aware back then of the importance of the living context for the continuation of performing traditions of intangible cultural properties, and of their holders. Furthmore, he emphasized the interactive aspect of performativity, which was to be created between audiences and performers. In contrast, current attempts at preservation of ICH in Korea display a rather strict adherence to fixed forms of performances, which are to be transmitted and enacted by the holders for both the Korean and foreign spectators.

\section{AMBIVALENCES}

Since its very beginning, Korea's concern about its heritage has been a governmental and scholarly affair. In the 1960s, when decisions were made on what was worthy of being called a "heritage", as already mentioned, differing opinions emerged, especially towards shamanism, the favorite topic of Yim Suk-jay. According to the recollections of Im Dong-gwon, a member of the Cultural Heritrage Committee, the common opinion was that shamans "'who deceived the people' could never be designated cultural properties 
and receive state assistance" (Soul 2012: 24). In opposition to that, Yim Sukjay argued that shamanism was the most genuine mark of Korean identity and the core of Korean culture, which he called muism ${ }^{14}$ (Yang, J. 2003: 26). Driven by his conviction, he founded the Association for the Study of gut (Guthakhoe) ${ }^{15}$ and, in spite of negative sentiments toward shamanism, he began collecting songs and stories of shamans in the northern part of Korea. Another heartfelt desire of Yim's was to encourage the younger generation to value, study, and eventually perform their traditional culture. In order to make that possible, in his role as an advisor in the creation of the Cultural Property Protection Law (CPPL) in 1962, Yim contributed significantly to the revival of tradition by organizing numerous festivals and folk arts contests.

In Korean CPPL, the "knowledgeable and skilled persons who maintained a particular art or technique" (Yim, D. 2004: 11) are called living national treasures (inganmunhwajae) or holders (boyuja). The government committee designating the properties and treasures additionally "maintain[s] the right to authorize or otherwise control the performance of designated items or the activities of the performers" (Yang, J. 2003: 39). The duty of living national treasures is "to perform their designated item in exact original form and to preserve it" (ibid.). To some extent this contradicts the concept of heritage that "seeks to sustain a living, if endangered, tradition by supporting the conditions necessary for cultural reproduction. This means according value to the 'carriers' and 'transmitters' of traditions, as well as to their habitus and habitat" (Kirshenblatt-Gimblett 2004: 53). However, in Korea we can observe an artificial cultural reproduction insisting on the preservation of only one form, exactly that at the time of designation and of a particular holder. Sometimes the items are taken out of their local habitat as well. In this vein, the natural life of an item is ignored but the "traditional form" is maintained "forever". Opponents of this definition of a property argue "that changing social conditions manifested in an item of intangible cultural heritage should be evident in its public performance, and that public interest in the petrified form of an item of intangible cultural heritage will vanish because today's audiences do not have the same tastes of those of the past" (Yim, D. 2004: 12). ${ }^{16}$ Both arguments are problematic insofar as the

${ }^{14}$ The term refers to Korean shamanism, the religion of $M u$ or shaman (mugyo).

15 The term means shamanic ritual.

${ }^{16}$ One such example is described by Yim and relates to the masked dance dramas in which performers utilize masks to communicate social criticism to the audience. As these dramas could not awake interest among the new generation, they were designated as items of the cultural heritage, and living cultural treasures who had knowledge and skills of their performance passed them on to their students. However, Yim notices that "among the young people (especially college students) who received instruction and learned these masked-dance dramas, however, some maintained that the texts were too rooted in the past, with no relevance to the youth of today. In order to make these dramas appealing, they advocated criticising current politicians and the wealthy heads of vast conglomerates rather than satirising the rul- 
first demands the preservation of the "original" form as of the time of its designation and deals with the question of meaning of originality (wonhyeong). The second argument, which supports the necessity of change, overlooks that each period of time will produce a new holder with a different/not yet defined item for transmission. Sometimes the dislocation of an item and its holder from their natural habitat to Seoul is also problematic. Looking at a determined form of Korean ICH in the modern context of the touristic quest for existential authenticity, this is less problematic. Traditional folk heritage, which moved from the villages to Seoul (not exclusively) and subsequently all around the world, developed such sophisticated and highly artistic forms, they being "authentic" in all shortened or newly created forms that could be always performed to the ever-changing audience. There may be potential in these intercultural movings to and fro, and in intracultural con-creativities, for raising a new "cosmoculture", as claimed by the anthropologist Lourdes Arizpe (2004: 130). ${ }^{17}$

We apply the term of con-creativity here as suggested by Rombach in his phenomenological approach, connecting it with the aforementioned notion of "event-ness". Each opening up of new ground for encounter between cultures or within one culture creates a new reality in terms of the growth of "never before experienced" authenticities. This is possible only through leaving behind old forms and creating a new "world", 18 meaning that the journey from one's own to an alien world can happen only as transfiguration and not just through exchange of certain commonalities.

Folk heritage thus transformed into traditional performing arts received the role of a national treasure: "The government-designated performer of a living national treasure then further reshapes tradition into a more sophisticated art form, continually representing tradition in a fixed context in order to maintain the wonhyeong (original) of the traditional performing art form" (Yang, J. 2003: 51). These discrepancies in the Korean elaboration of the nature of ICH itself cannot be resolved easily. If the process of designation allowed contextual changes of a particular item through interactive communication between audience and performer in the village, each form preceding the change would be lost. Yet, it would open space for creation of new forms of the item, as seen in the case of the masked-dance dramas and farmers' folk music (nongak), both utilized in student's anti-government

\footnotetext{
ing class of former times. And instead of using texts filled with archaic and unfamiliar vocabulary, they argued that texts using modern language should be substituted and transmitted" (Yim 2004: 12).

17 "Cosmoculture" implies "a global perspective of constantly evolving human creation and communication" (ibid.).

18 "Welten entstehen nur in 'Konkreativität'. Dies besagt, dass sie nur dann aufgehen, wenn es dem Menschen gelingt, vorgegebene Möglichkeiten der ihn umgebenden Wirklichkeit so anzugehen, dass daraus höhere Möglichkeiten entspringen" (Rombach 1991: 52).
} 
demonstrations in the 1980 s or in the most newly created artistic items of the last fifteen years.

\section{PRACTICE}

During the Gukpung 81 (Wind of the Nation 81) festival and the Summer Olympic Games in 1988, the aim of the government was to substantiate their new programmes, while claiming to be willing to support traditional Korean heritage. In the case of the 1988 Summer Olympic Games, through "performing heritage" on numerous stages around Seoul, the government not only promoted its new ideologies of Northern Policy, but also the beauty and refinement of Korean culture, its mentefacts condensed in a series of visible patterns, "where the social, individual, physical and psychic meld into a unique expression, in itself total and global" (Dubé 2006: 126). As for Gukpung 81, Yang Jongsung (2003: 90) notes:

To fulfill its propagandistic purpose, efforts were taken for this festival to include the whole nation. Not only regional performers, but their audiences as well were brought to Seoul by tour buses. [...] The general public [was] not aware that traditional cultures and their performers by being in the parade were being associated with a political agenda.

A similar phenomenon could also be observed during the Olympics, when traditional culture from various regions of Korea became a spectacle with no connection to the everyday lives of Koreans. Most of the Koreans Snježana Zorić interviewed at that time were not familiar with those traditions and had never seen them. Still, they continue to live on various stages, while new meanings and functions keep being attributed to them. In this sense, Kirshenblatt-Gimblett rightly argues "that heritage is a mode of cultural production that gives the endangered or outmoded a second life as an exhibition of itself” (2004: 56). This contradicts “one of UNESCO's criteria for designation as a masterpiece of intangible heritage [which] is the vitality of the phenomenon in question: if it is truly vital, it does not need safeguarding; if it is almost dead, safeguarding will not help" (ibid.). But how can UNESCO's criteria for designation be met if the potential treasure is required to be traditional, contemporary and living, all at the same time?

It is also interesting to mention that some holders of tradition do not always follow the rules defined by the government, but are continually changing the form of the designated item. However, this does not always happen in the natural environment within the community - since many holders are living in Seoul - but according to their own creative imagination and un- 
derstanding of the ongoing processes between the performer and his art. Yang describes example of Lee Mae-bang who kept changing the steps of the seungmu dance he was designated to transmit each time during his teaching classes. Thus, each performance of this popular Korean dance became a new creation without any fixed choreography. ${ }^{19}$ As Lee's student of seungmu, Yang tried to discuss this matter with the Master himself, further enquiring whether he was not concerned about the possibility of being erased from the list of ICH due to these constant changes. Lee, however, was not impressed by the duties imposed on him by the CPPL, arguing that, in any case, he was the one and not the government who knew the original form of the dance. According to Lee, the constant variations in his choreography were not arbitrary alterations, but the "real" original steps that he happened to remember anew during each one of his performances. Therefore, "he maintains that his changes are not innovations, but rather the regeneration of old 'wonhyeong' (original) steps newly integrated" (Yang, J. 2003: 67). Evidently, in the case of Lee, the legal compulsion to preserve a certain dance form contradicted his natural and personal vision of how to give life to the property he was designated to transmit.

Before entering further discussions on professionalization of ICH and its impact on the authenticity of intercultural encounters, let us take a brief look at another aspect of Korean ICH through a point raised by Arizpe, namely that "cultures and religions have increasingly been taken up as political ideologies" (2004: 132). This applies strikingly to some periods in Korean history. Because they were supported by the government, performers had to participate in various political functions (such as the aforementioned 1988 Summer Olympic Games and Gukpung 81 festival). Their performances were not put up to showcase their artistic value or for the sake of safeguarding, but instead they were controlled and manipulated to serve the current agenda of the government. Yang argues that through such processes "Korean tradition has been transformed into symbols of the nation's cultural heritage, rather than serving as expressions of that culture" (2003: 88).

In a similar vein we could observe the performances of Buddhist and shamanic religious rituals already transformed into art forms as performed during the Olympic Games in 1988. It was around that time that Snježana Zorić started research on Yeongsanjae, a Buddhist ritual conducted to console and lead the ancestors' souls to heaven (Zorić 2004). ${ }^{20}$ As a performing art, this ritual already had a long tradition since it had been designated as intangible cultural asset No. 50 as early as in $1973 .{ }^{21}$ Its form was fixed

\footnotetext{
${ }^{19}$ For more about seungmu see in Van Zile (2001).

${ }^{20}$ We are mentioning this case study separately from others that follow because of the time distance connected to that particular field research.

${ }^{21}$ UNESCO added it to its Representative List of the Intangible Cultural Heritage of Humanity in 2009.
} 
while its function was changeable from one occasion to another - religious, political, entertaining or, once a year, simply for the sake of safeguarding performance according to governmental demands. Variations could affect duration, order and the parts chosen to be performed. Through interviews with the performing monks, Zorić came to know that the ritual originally was not just symbolically representing but in fact reactualizing the event of the Buddha's preaching of the Lotus sütra on the Yeongcheuisan mountain. The particular performance Zorić witnessed in 1988, however, had the sole purpose of bringing about a successful outcome for Korea during the Olympic Games. Furthermore, the monks mentioned that Yeongsanjae could also be performed to actuate Korea's unification, an issue that was the political terminus ad quem at the time. Several years of research conducted later in the Beongwon temple, where the tradition of Yeongsanjae is cultivated, led to the insight that Yeongsanjae, in spite of its formal determination, was still alive in its traditional religious context - sometimes Buddhist laymen ordered the ritual on a small scale for their own ancestors. According to the interpretation transmitted by the monk performing the peopkochum, this dance was to evoke the idea of transcending samsāra and nirvāna; the moment of transgression was realized, therefore experienced, in the heavy drumming at the end of the dance. Interestingly, the dialectic of the experience is not limited only to the dancing monk, but is transferable to the ancestors as well, so that they may collect merit, improve their karman and ascend to higher levels in their future rebirth. The authenticity of the monk's performance guarantees the transformed state of the ancestors. Nowadays, twenty-five years later, this story is narrated but hardly felt experientially, while the ritual is being performed for profane and festive purposes. Zhu (2012: 1501) describes a similar case of the Dongba religion in Lijiang, China as "a new form of valued culture [...] vividly represented in ritual performances, folk festivals, music and dance, [that] has been revitalized and staged in the tourism market as a religious cultural product".

\section{AUTHENTICITY OF SUBJECT, OBJECT AND NEW CREATIONS “IN-BETWEEN"}

It seems to be a general trend of the one world market to induce another kind of rebirth of ICH, not only to safeguard but also to transform it through interculturalizing processes into universal, placeless and timeless property. The performances are supposed to target international audiences, preserve the value and uniqueness of cultural differences but express themselves through universalizing values of human culture. In accordance with the opening of new horizons in the aforementioned project, Korea Culture and Art 2014, 
culture and art should expand the boundaries of what is traditional, while being brought to perfection even more intensely in order to be able to raise attention, impress and fascinate spectators at home and abroad.

What is the potential of this newly shaped cultural heritage in the growing intercultural situation and in the debate on existential authenticity attached to it in the context of heritage tourism? Obviously the meaning of heritage has undergone many changes in the course of its use (Steiner and Reisinger 2006; Kim and Jamal 2007; Zhu 2012). First it was clearly tangible, it was an object worthy of being preserved, and, to paraphrase Munjeri, an expression of cultural and historic truth. Additionally, "central to all is the issue of values and valorization: what qualified as cultural heritage was deemed to be stable, and static and having 'intrinsic values' as well as qualities of 'authenticity'" (Munjeri 2004: 13). According to Munjeri, the Convention Concerning the Protection of the World Cultural and Natural Heritage (1972) defines authenticity as follows: "'authenticity in materials' based on physical values or fidelity to the object; 'authenticity in workmanship', this consistent with the notion that physical products entail creative genius; 'authenticity in design', values based on the creator's (architect, engineer, etc.) original intention and 'authenticity in setting' or fidelity to context, i.e. values contingent upon locus and spatial considerations" (ibid.). ${ }^{22}$ Munjeri's argument highlights the importance of narration about cultural and social value implied in intangible heritage. While elaborating on his thesis more profoundly, he quotes the Nara Document on Authenticity (1994) which "called [...] for a widening of the framework of 'authenticity' to include traditions, techniques, spirit, feeling, historic and social dimension of cultural heritage" (ibid.: 16). Intending to show the difference and after that the convergence between tangible and intangible heritages, Munjeri quotes Appadurai (2004: 18):

[I]ntangible heritage because of its very nature as a map through which humanity interprets, selects, reproduces and disseminates cultural heritage was an important partner of tangible heritage. More important it is a tool through which the tangible heritage could be defined and expressed [thus] transforming inert landscapes of objects and monuments turning them into living archives of cultural values. ${ }^{23}$

The continuity of dialogue between values and norms of traditional Korean society with the modern, and the correlation of tangible heritages and in-

${ }^{22}$ Tangible heritage sites are fulfilling these demands by applying authentic material (recent restoration of Gwanghwamun etc.), workmanship (in building new Buddhist temple halls), design (in dancheong paintings) and many other ways.

${ }^{23}$ For Munjeri, sustaining heritage is deeply connected with the "equilateral triangle relationship" between society, norms and values (2006: 18). 
tangible meanings with their rich symbolism attached to them, are broken. Thus the artists have to search for new narrations - as in contemporary performing arts - or new forms to meet intercultural demands. It is not the past that is repeated in present artistic creations, but the present looking into past forms, reconsidering, rethinking and recreating them as new forms. Introducing the concept of authenticity into the ongoing discourse of cultural policy, tourism and creative economy, as exposed by Kim Hye-in, could be helpful in setting priorities for the Korea Culture and Art 2014 project. Kim sees the main goal of the project in promoting the exchange of cultural forms for the sake of initiating a new kind of international co-operation and intercultural communication. However, this issue has to be treated in a very sensitive manner due to the ambivalence that permeates Korean understanding of multicultural/multiethnic society and the intercultural communication in this society. From the perspective of their self-understanding, Koreans belong to one of the most homogeneous nations in the world and they would like to keep it that way (Savada and Shaw 1990: "The Society: Population", see also Hong 2013: 33). Changes in the social and economic environment are not treated in the same manner as those in cultural and intercultural domains. The arrival and settling of immigrant workers in Korea is not supposed to bring about any changes in society (!), whereas in the field of art, transformations and new creations through intercultural encounters are considered desirable. The growing awareness of ambivalences toward the Other has given impulses for governmental support of mutual meetings and exchange of social practices between foreigners working or studying in Korea and Koreans. However, according to one example described by Hong (2013: 38), the Korean way of "interculturalizing" means two buses with exclusively Korean or foreign passengers going to one destination where they will share a common meal, present themselves - without knowing the language of the other - and "get to know" each other by having a good time. Even though the concept of damunhwa or multiculturality has entered academic and journalistic discourses and is now more present in people's minds, its hermeneutical potential in creating mutual understanding is recognized only theoretically, while its implementation follows a clear-cut distinguishing of one's own and the Other and their incommensurabilty. Intercultural encounters are restricted to certain domains and the multicultural societies exist somewhere outside the Korean world but not within it. The attempts to enter the realm of dialogical culture that focus on the Other living in Korea is still not happening (Hong 2013). But the desire "to be understood" and perceived through various achievements, e.g. in information technology (IT) or heritagization of cultural presentations around the world, is the clearly recognizable governmental intention. This means that the endeavours in the hermeneutical play of understanding within the intercultural dialogue 
are geared only towards being understood, while to understand the Other is dispersed in diverse forms of "Koreanization". "Multicultural policy in Korea primarily intends to harmonize with existing condition in Korea, discriminating everything non-Korean, especially other Asian people" (Hong 2013: 37).

\section{TRANSFIGURING IN “BETWEEN"}

So how to create an intercultural dialogue that could effectively transcend animosities and refusals caused by cultural diversities? The Korean wave (hallyu) represents a new interculturally created "heritage", which is currently sweeping across the globe. ${ }^{24}$ At a press conference (Seoul, November 2013), Lee Bae-yong, president of the Academy of Korean Studies, emphasized the academia as the driving force in Korean culture promotion. Extensive studies of Korean history are also seen as a boost to the cultural products of the country, contributing to further spreading of the Korean culture wave. According to Lee, Hallyu 3.0, as an academic "turn", could provide cultural products with depth and grounds for further "storytelling" (Bae 2013). When looking at the social and cultural realities in the Korea of the 21st century and considering further significance of ICH, Koreans might, apart from the intercultural dialogue, continue the already started intra-cultural dialogue with their own heritage tradition..$^{25}$ The interest of the younger generation in tradition should be rekindled by transforming heritage into more contemporary forms to be able to enter the intra-dialogical scene at all. Because the interest in traditional Korean music and dance at home is currently very low, some theoreticians have already suggested introducing these traditional arts into the educational system. If this were done, children would start to learn and appreciate these forms of the Korean traditional culture from an early age. For this purpose, specialized new hagwons ${ }^{26}$ should be opened.

There are also attempts by theatre makers to stage performances for children combining traditional and modern music and dance elements. Furthermore, new dance and theatre companies are trying to con-create works combining Korean native forms with modern and Western forms in order to make them more captivating for Koreans themselves. All of these efforts suggest that, in the process of familiarizing people with their own culture, the authenticity of the culture in terms of its antiquity ends up being sacrificed

\footnotetext{
${ }^{24}$ More on the Korean cultural wave or hallyu in Kim, S. H. (2013).

25 "It is a rare and meaningful development that non-Anglo, non-Western culture has permeated into Western society, though it may be limited to pop culture", as was pointed out by academy official Lee Dong-hee on the same occasion (ibid.).

${ }^{26}$ The term refers to for-profit private organized teaching on any subject taught in the regular school or academy for teaching additional subjects like music, dance etc.
} 
to a certain extent. ${ }^{27}$ From various interviews with students we learn that, for example, Korean gugak traditional music is perceived as being boring because of its lack of melody, numerous repetitions and its noisiness. Korean traditional dance is seen as either too slow or too dynamic and acrobatic, depending on whether it belongs to court or folk tradition. Apart from such stereotypical notions, there are also some contradictions within the Koreans' perception of their heritage. When questioned about the value of their national heritage, the respondents expressed a high sense of appreciation, pride and respect for it, even though they could not, in fact, name one single property. In that sense, the Korean past is actually persisting in an abstract memory archive. If Korean heritage as representation of the past has become the Other for Koreans, one cannot but wonder how it could possibly have potential to become a source of existential authenticity for the other Other.

\section{EXISTENTIAL AUTHENTICITY}

Concerning this matter, it is worth taking a look at a debate by Steiner and Reisinger (2006) that departs from a philosophical perspective and its long history of searching for existential meanings. Here, the authors test whether "Heidegger's concept of existential authenticity holds considerable promise as a conceptual framework for exploring the idea of authenticity for tourists and hosts" (Steiner and Reisinger 2006: 300). The basic outlines already show how multi-layered the concept of authenticity is and how strongly it is connected with the idea of embodiment as a precondition for our understanding of reality. As such, the concept of authenticity is interactive, intersubjective and intercultural; if we look at it phenomenologically, it adds the dimension of "inter", i.e. "in-between", to the Heideggerian dwelling, in which encounters may take place. "Dwelling is the intimate relationship between each Dasein and its world which mutually determines, limits and obligates each and both" (ibid.: 302). In the course of the current increasing awareness about and search for existential and experiential authenticity, it seems that the dwelling within one's own life-world does not possess the capacity to provide authenticity of life. Its signature is "longing for escape" and departure from social norms and role-playing that determine the way of living within it. Such understanding of the existential situation lacking authenticity makes people long for experience. As experiences are transient,

\footnotetext{
${ }^{27}$ We can observe this in the world famous Korean theater, KARMA, which combines art dance and martial arts with fancy costumes. Director of the company, Woo Jae-hyon, also emphasizes the practice of communication with audiences and the synesthetic experience they want to induce in them during the performance as a part of making the own culture less strange.
} 
so is the existential self. "It changes from moment to moment. As a result, a person is not authentic or inauthentic all the time. There is no authentic self. One can only momentarily be authentic in different situations" (ibid.: 303). Therefore, apart from rare authentic moments, life is full of inauthenticity. Heidegger a-scribes it to conformists and de-scribes them as those who persue "the possibilities of anyone and consequently have the experiences of anyone rather than their own experiences. The loss of individual identity that comes from inauthenticity might be behind the number of scholars who see tourist activity as a quest for new and significant experiences outside of routine life" (ibid.: 306).

Korean ICH is mostly "staged"; as such it satisfies governmental demands and guarantees the authenticity of an item and performing skills of the intangible human heritage responsible for its transmission. ICH can also be learnt in training and education centres - this experience may be culturally, artistically or religiously authentic. Being all-inclusive, these offers are mainly designed for groups and always follow the same performative procedure. Some people do, however, experience them as authentic, even though according to Steiner and Reisinger they lack mineness, i.e. "possibilities of their own that are not shared with others" (ibid.). While interviewing participants in the Seoul Intangible Cultural Heritage Center (Gyoyukjeonsijang), we found the opposite, i.e. that mineness is not crucial to experientializing authenticity; more important is the sharing of emotions and acting together, generating joy in the differential space of "in-between" while, at the moment of encounter, a deep experience of event-ness does not appear. MacCannell positions the authenticity in the strange world because "reality and authenticity are thought to be elsewhere" (1976: 3) and it is in there that they may be triggered. Thus, the condition of the possibility to existentialize experience and become authentic demands fundamental displacement and further metamorphosis.

In their description of the Texas Renaissance Festival, Kim and Jamal (2007: 184) apply van Gennep's and Turner's concept of liminality to explain existential authenticity:

Liminality [...] is also an important concept for understanding the attainment of authentic selfhood and unmediated intersubjective experience. [...] liminal spaces [...] provide tourist license to participate in temporary forms of transgressions that enable their secret selves to be displayed while pursuing unrestrained hedonic experience.

Can liminality, indeed, be the place of authenticity? Why does authentic experience originate in the "strange"? Through which mechanism does a momentary artificial role in the event become more authentic? Is it connected to deferring in time and space? What has changed, the self or the perception 
of self? Why is the acquainted other self, emerging through intracultural or intercultural encounters, more authentic than the own self? Such liminal experiences would not fit the Heideggerian concept suggested by Steiner and Reisinger. Consequently, Kim's and Jamal's case of the Texas Renaissance Festival is an example of an inauthentic experience; it is neither con-creative nor event-ful.

\section{KOREAN CASES}

The next case exemplifies how Buddhist monks offer guests cultural insights into the everyday lives of monks within the few days of Templestay. Another possibility is to follow and practise traditional rules of the monks' life for a longer period of time without ordination and authentically experiencing parts of the Buddhist religion. In both cases this practice is mimetic and we call it cultural experience. The guests observe and imitate the actions of the monks in their everyday routines. They also include a daily class on the Buddha's doctrine. While the observers' attention is focused on the monks, their knowledge is expanded through becoming acquainted with the monks' different forms of life. The level of embodied practice is arbitrary, since one can engage in the event or just look at it. But religious experience, unlike cultural experience, requires more, from in-depth studies of Buddhist teachings to simultaneous implementation into the practice of self-cultivation. The emphasis here shifts to one's own self or more precisely to eliminating it. A search for religious experiences is deeply rooted in the existential need of practitioners to reach an enlightened mind and their desire to live in harmony with their own nature, which is one with the Buddha. Here in this context, according to Heidegger, the cultural experience would be inauthentic, but the religious experience is deemed authentic. ${ }^{28}$

In October 2013, we conducted field research in the Geumseon temple, while taking part in the weekend program of Templestay. Our group consisted of three Koreans, three Americans, one Japanese and a family from Bulgaria. After entering the temple compound, we were requested to change our clothes and dress in temple robes, which symbolized separation from our everyday life and entering liminal space. After that we visited the temple halls, while the nun explained the meaning and function of each and every one of them. The nun also introduced basic elements of the Buddhist teach-

\footnotetext{
${ }^{28}$ Here we would like to draw attention to the fact that, in the context of Buddhism, the research on being authentic or inauthentic in relation to one's own self can easily overlook the main idea of Buddhist authenticity, which is that there is no self at all (anätman). While Western understanding of authenticity focuses at realizing one's own self, Buddhist understanding and practice aim at liberating oneself from and annihilating one's own self.
} 
ing necessary to understand the following procedures. The purpose of our group visit was clearly culturally framed. After entering the main temple hall in the evening, we were taught the way of bowing and taking refuge in the Buddha - Bucheonim, his teaching - dharma (beob), and the community of monks - sangha (seung), known as the Three Jewels of Buddhism. The sacred Buddhist texts, sūtras, were sung and the nun explained that the singing caused the mind to become calm and pure. After that, we were free to decide whether we wished to perform the 108 prostrations, which is the practice of cultivation of self. Each bow stands for the repentance of one of the 108 illusions; performing them is said to fill the practitioner with positive energy. This part was very tiring and most of the visitors retired to their rooms. The aforementioned Bulgarian family did not practice at all because it would have contradicted their own religion; performing rites of another religion meant sinning against their faith. The next day, according to the rules of temple life, we woke up at 4:30 a.m. After taking a bath, we had to prepare for morning rituals consisting of yoga meditation, prayer and a communal meal (baru-gongyang). Yoga meditation was introduced to us by another nun, who explained it as an active practice increasing the understanding of our mind's functioning. It was amazing to observe her movements, which skillfully combined yoga and Korean martial arts, but none of us was able to perform any of them. During this corporeal practice, the mind is tranquilized and unaffected by outer sensations, so that the individual would be able to enter the path towards ultimate enlightenment after taking refuge in the Three Jewels and cognizing the three constitutive signs of existence, namely suffering, impermanence, and no-self.

The communal meal that followed after the practice was a ritualized way of taking in food according to a strict procedure. Sitting in rectangular order, everyone received their own "monk's" utensils and arranged their bowls according to the nun's explanations. The emphasis was laid on the awareness of the quantity of food one was about to ingest, because all food had to be consumed and nothing was allowed to be thrown away. Thus the eating process became very conscious and free of greed that could cause overeating. We will not describe the whole complex procedure but the final part is worth mentioning, as it concerns the concept of existential authenticity. It is the rite of cleaning the bowls that is carried out by pouring water from one bowl into another, while at the end, the rinsing water is to be drunk as well. Some of the participants could not overcome their feelings of disgust and did not ingest the water. Of course, as "cultural" practitioners we could refuse to do this, but for a "religious" practitioner, it would have been an existential and iconic basic experience of the Buddhist being-in-the-world, i.e. disgust and suffering. Our Templestay, on the other hand, was merely an experience of the Buddhist traditional life-style as an exhibition; it was a life-museum of 
sorts which one could visit, pay attention to objects, practices and stories of one's choice, and was then free to leave.

Similar ambiguities could be observed during our sojourn in the Seonbichon Village and Sosuseowon, the first Confucian academy supported by the Joseon King Jungjong (1543) to hold a memorial service to An Hyang (1243-1306), a great Confucian seonbi from the Georyo times. ${ }^{29}$ Both are located in the vicinity of Yeongju, the city famous for many seonbis or Confucian scholars. Seonbi embodies the image of a perfect man of virtue, educated in Mencius' ideas of humanity and righteousness, and respecting family tradition together with the ancestor cult. Honorableness, patience and, above all, self-discipline are the highest virtues of the seonbi. Seonbichon is built as a site where the mindset and wisdom of traditional scholars could be transmitted to modern Koreans. It restores the place where Confucian scholars lived and studied together. It is divided into four sections, the name of each standing for the value they uphold: susinjega (cultivating oneself and putting family in order), ipsinyangmyeong (winning success and fame), geomugwan (not seeking ease in the dwelling place), udoburubin (feeling ashamed of one's poor scholarship, but not about one's material poverty). According to the explanations of the tourist guide, the whole village and not only the academy were constructed to show the original life style of the ancient people of Yeongju. Each house displays traditional furniture and household utensils used by different classes of people. Everything is arranged to provide diverse images and experiences for the visitors.

As Confucianism has been considered an important spiritual philosophy of Koreans for a long time, a Sosu Museum was built in the vicinity, designated to exhibit systematically a wide range of traditional Confucian culture assets. The aim is to help guests trace back the historical roots of the national spirit of Koreans, while offering a chance to experience some of them in their local context, for example, during the regularly held Seonbi Culture Festival. Apart from that, the Korean Seonbi Cultural Training Center is also located in the village, which aims to foster global human resources and leaders by providing human-oriented training and education in accordance with the seonbi spirit. The centre consists of seventeen Korean-style buildings, including five buildings for manners education and hands-on cultural experience, six loading facilities with a 150 people capacity, four traditional tea houses, and other conveniences. The current mission of the centre is to teach how to advance professionally as well as to provide job training in general. Big companies usually send their employees to learn the seonbi etiquette and the rules of

${ }^{29}$ Within the Sosuseowon are several buildings including the Ganghakdang School (National Treasure No. 1403) used for study by Confucian students, and Munseonggong Tomb (National Treasure No. 1402) built to enshrine memorial tablets of An Hyang, An Bo, An Chuk and Ju Se-bung. The portrait of An Hyang (National Treasure No. 111) is enshrined in the Hakgujae building within the Sosuseowon. 
proper behaviour. Talking with those responsible for the organization of the centre and its mission, I found out that most people coming to the center were not familiar with the elementary ethics of Confucianism and needed to be educated in the subject. ${ }^{30}$

It is striking that all students visiting the centre are exclusively male Confucian tradition never was and apparently still is not part of the female life domain. We found out, however, that to most participants, this training was more about life decorum and self-staging than it was about authenticity; but as artificial as this decorum may be, when applied in an intersubjective communication and self-presentation, it represents the expected social "authenticity" of an educated Confucian scholar or polite Korean adult, who respects tradition and lives according to it.

Another interesting example of implementation of ICH that we observed was at the Seoul Nori Madang, an outdoor stage established in 1984 with the aim of promoting Korean folk plays and culture. Most of ICH items such as nongak, seungmu, salpuri, Songpasandaenori etc. are presented here yearly from April to October. ${ }^{31}$ These performances are generating another kind of existential authenticity among audiences, defined by Brown (1996) as "a state of being that is activated by tourists when having a good time" (Steiner and Reisinger 2006: 301). The performers at Nori Madang have brought their art to perfection and according to their self-understanding their performances suggest authenticity. Still, the performances were not perceived as more than commoditized entertainment by most of our interlocutors. The communicative dimension between performer and audience, which is supposed to contribute to natural interactive evolvement of traditional folk items, is reduced to members of the spectating crowd yelling occasional interjections of approval or rejection. Nevertheless, it would often happen that some audience members got carried away by the rhythm of the music, dance and energetic atmosphere, and actually entered the stage and participated in the performance itself, much to the amusement of the rest of the audience and the annoyance of security guards trying to catch them in the crowd of the real dancers and musicians. However, when asked about the authenticity of their experience after watching the performances, most of the respondents did not understand the point of our questions. Seoul Nori Madang is a place of entertainment, and in spite of the performative perfection it is obviously not able to leave residual impressions but only spontaneous momentary impact. Thus, "authentic" ICH cannot automatically generate "authentic" experiences.

${ }^{30}$ As with most of Korean heritage, it is not a lived part of family tradition or social interrelationships anymore, but reduced mainly to Thanksgiving or Chusok celebrations and the New Year's (Seollal) rite of bowing, sebae.

${ }^{31}$ For more details see Van Zile (2001), and Howard (2012). 
Snježana Zorić and Kim Sang Hun, The Intercultural Potentials of Intangible... NU 51/1, 2014, pp 155-181

\section{CONCLUSION}

In conclusion, our cases, i.e. the Buddhist ritual Yeongsanjae, Templestay, Confucian Seonbi tradition, and traditional folk performances at Seoul Nori Madang have shown the urgency of re-thinking the current intracultural situation in Korea regarding the preservation of national traditional heritage and its revival by, for example, reintroducing it into artistic production or the educational curriculum and, thereby, into everyday life. Whether it will ever become a part of daily life again shall remain open at this particular moment. "Authentic" experiences on an intercultural level could be observed mostly in religious and artistic contexts, where con-creative processes may happen at a certain point in time. The concept of event-ness in the space of "in-between" is more an appropriate interpretive term in the field of artistic dialogue between traditional heritage and new artistic creations than it is in the encounter between the "performing heritage" and the touristic consumer of everyday intercultural encounters.

As it seems, ICH in Korea is either living its second life or dying its second death, depending on the perspective. It could be "second life" because after the Japanese colonization and the Korean War, conscious efforts were made to keep tradition from sinking into oblivion, to revive and present it as a genuine sign of national identity and pride. "Second death" happened just after the revival, when the government rigidly prescribed strategies for protection and preservation, fixing the form of heritage exactly as it was at the time of its recording, when the informants became living human treasures responsible for the transmission of exactly this fixed form. In their attempts to make the past present, Koreans othered their heritage twice - first they revived it as a certain remembered form, then they ended it by declaring this form unchangeable. Thus ICH lacks not only continuity in time between ancestors and their descendants; establishing a positive reception among younger generations proves difficult as well. Despite all that, ICH is a real and symbolic part of Korean social and cultural life, contesting its new positions and negotiating its new meanings and functions. Paradoxes bound to this issue keep inspiring new discussions, considerations and practices with the "awareness that conservation can no longer be based on the object's intrinsic quality. It must be founded on our ability to recognize its aesthetic, historic, scientific, social values etc., or rather, it is society, the community that must recognize these values, upon which its own cultural identity can be built" (Vecco 2010: 323).

Looking back at Kearney's phenomenology and our understanding of interculturality, we would like to accentuate that all encounters in the space "in-between" and their consequences are new creations - they belong to none of the interlocutors. Their constitutive elements are those unspoken 
and invisible moments recognized in a special atmosphere (bunwigi), raising implicitness of understanding in the interacting process, communication or artistic performance. And it is the ongoing attempt among Korean artists to keep their heritage alive through such dialogic encounters, which live not only through words but also through affection, empathy, and commitment. Zhu also recognizes the importance of the space "in-between" and the atmosphere: "the search for authenticity is not only related to toured objects, socially constructed reality as a projection or the existential feeling of selfness, but also has to do with what happens in between" (Zhu 2012: 1498), sharing this view with Rickly-Boyd, who instead of atmosphere talks about aura in Benjamin's sense (ibid.).

With regard to the Korea Culture and Art 2014 project, a new meaning and practice of existential authenticity as well as of performing heritages has to be created from the vantage point of cultural and creative economy. All this has to be under the banner of the postmodern approach that is characterized by the aporetics of searching authenticity by deconstructing it. As Ning Wang quoting Eco (1986) rightly points out, we need to be cautious about "destructuring the boundaries between the copy and original, or between sign and reality" (Wang 1999: 356), or authentic and inauthentic. Following Eco's idea of hyper-reality, Baudrillard (1983) introduces the concept of simulacrum, which suspends the difference between the real and non-real, original and reproduction. Tradition is just as real as the new artistic concreated forms, which have emerged from intercultural dialogic artistic or religious encounters and their event-ness, be it for tourists or truth- seekers. According to Cohen (1995), a "playful search for enjoyment" and "aesthetic enjoyment of surfaces" suffice for a postmodern tourist (ibid.: 357). The contradictoriness of subjective evaluation of authenticity requires further reflections if we are to gain an understanding of that which is going on "in-between" our immediate intercultural encounters - is it an emic "going native" or following one's own self? Thus, in the context of creative economy, we have to recognize the dual nature of heritage, as a cultural treasure aiming to metamorphosize the observer and as a marketing product having the potential to promote sustainability for heritage, their performers and their audiences. In this sense, the cultural actors and policy-makers are more and more involved in the elaboration of the potentials of intercultural dialogue and increasing interest in shared universals of life-world imaginaries opening up spaces of raising possibilities for experiencing existential authenticity.

\section{ACKNOWLEDGEMENT}

This work was supported by Hankuk University of Foreign Studies Research Fund of 2014. 


\section{REFERENCES AND SOURCES}

Arizpe, Lourdes. 2004. "Intangible Cultural Heritage. Diversity and Coherence". Museum International 56/1-2: 130-136. [http://dx.doi.org/10.1111/j.1350-0775.2004.00467.x]

Bae, Ji-sook. 2013. "Chief of Korean studies academy declares 'Hallyu 3.0”'. The Korea Herald, 27 November 2013: 16.

Davies, James. 2010. "Introduction. Emotions in the Field". In Emotions in the Field. The Psychology and Anthropology of Fieldwork Experience. James Davies and Dimitrina Spencer, eds. Stanford: Stanford University Press.

Dubé, Philippe. 2004. "The Beauty of the Living". Museum International 56/1-2: 122-129. [http://dx.doi.org/10.1111/j.1350-0775.2004.00466.x]

Heyman, Alan C. 2011. "Is Korea looking after its cultural heritage? More to do, but a lot done". The Korea Herald, 25 October 2011: 4.

Hong, Sogu. 2013. "Multikulturalizam u Južnoj Koreji. Izazov različitosti”. Književna smotra 45/2 (168): 33-40.

Howard, Keith, ed. 2012. Music as Intangible Cultural Heritage. Policy, Ideology, and Practice in the Preservation of East Asian Traditions. Farnham, Burlington: Ashgate.

Kearney, Amanda. 2009. "Intangible Cultural Heritage. Global Awareness and Local Interest". In Intangible Heritage. Laurajane Smith and Natsuko Akagawa, eds. London, New York: Routledge, 209-225.

Kim, Hyounggon and Tazim Jamal. 2007. "Touristic Quest for Existential Authenticity". Annals of Tourism Research 34/1: 181-201. [http://dx.doi.org/10.1016/j.annals.2006.07.009]

Kim, Soo Hwan. 2013. "Korejski val (Hallyu) iz kulturno-semiotičke perspektive. 'Kulturni prijevod' i južnokorejska popularna kultura”. Književna smotra 45/2 (168): 5-11.

Kirshenblatt-Gimblett, Barbara. 2004. "Intangible Heritage as Metacultural Production". Museum International 56/1-2: 52-65. [http://dx.doi.org/10.1111/j.1350-0775.2004.00458.x]

Köhler, Henning. 2001. Vom Ursprung der Sehnsucht. Die Heilkraft von Kreativität und Zärtlichkeit. Stuttgart: Freies Geistesleben.

MacCannell, Dean. 1976. The Tourist. A New Theory of the Leisure Class. New York: Schocken Books.

Munjeri, Dawson. 2004. "Tangible and Intangible Heritage. From Difference to Convergence". Museum International 56/1-2: 12-20. [http://dx.doi.org/10.1111/j.13500775.2004.00453.x]

Rombach, Heinrich. 1991. Der kommende Gott. Hermetik - eine neue Weltsicht. Freiburg: Rombach Verlag.

Savada, Andrea Matles and William Shaw, eds. 1990. South Korea. A Country Study. Washington: GPO for the Library of Congress. Available at: http://countrystudies.us/south-korea/ (accessed 1 July 2013).

Soul, Ho-jeong. 2012. "The Hidden Friends of Living Human Treasures". Koreana. A Quarterly on Korean Culture and Arts 26/3: 22-25. Available at: http://www.koreana.or.kr/months/ album.asp?lang=en\#k (accessed 21 January 2014).

Steiner, Carol J. and Yvette Reisinger. 2006. "Understanding Existential Authenticity". Annals of Tourism Research 33/2: 299-318. [http://dx.doi.org/10.1016/j.annals.2005.08.002]

Van Zile, Judy. 2001. Perspectives on Korean Dance. Middletown: Wesleyan University Press. 
Vecco, Marilena. 2010. "A Definition of Cultural Heritage. From the Tangible to the Intangible". Journal of Cultural Heritage 11/3: 321-324. [http://dx.doi.org/10.1016/j.culher.2010.01.006]

Wang, Ning. 1999. "Rethinking Authenticity in Tourism Experience". Annals of Tourism Research 26/2: 349-370. [http://dx.doi.org/10.1016/S0160-7383(98)00103-0]

Yang, Jongsung. 2003. Cultural Protection Policy in Korea. Intangible Cultural Properties and Living National Treasures. Seoul: Jimoondang International. (Korean studies dissertation series, no. 3).

Yang, Sung Chul. 1999. The North and South Korean Political Systems. A Comparative Analysis. Seoul: Hollym.

Yim, Dawnhee. 2004. "Living Human Treasures and the Protection of Intangible Culture Heritage. Experience and Challenges". ICOM News 57/4: 10-12. Available at: http://icom.museum/fileadmin/user_upload/pdf/ICOM_News/2004-4/ENG/p10_2004-4.pdf (accessed 14 January 2014).

Zhu, Yujie. 2012. "Performing Heritage: Rethinking Authenticity in Tourism". Annals of Tourism Research 39/3: 1495-1513. [http://dx.doi.org/10.1016/j.annals.2012.04.003]

Zorić, Snježana. 2004. Yŏngsan taejae. Buddhistički ritual kao zrcalna slika korejske kulture. Zagreb: Institut za etnologiju i folkloristiku.

\title{
INTERKULTURNI POTENCIJALI NEMATERIJALNE KULTURNE BAŠTINE U KOREJI: EGZISTENCIJALIZIRANJE ISKUSTVA I KREATIVNA EKONOMIJA
}

\begin{abstract}
SAŽETAK
U ovome radu riječ je o nematerijalnoj kulturnoj baštini i mogućnostima njezine zaštite i reprezentativne funkcije u promoviranju korejske kulture diljem svijeta ali i primjene u kontekstu kreativne ekonomije i razvoja samoodrživosti te turističke ponude kao njezinoga važnog konstitutivnog dijela. Tematizira se i pitanje egzistencijalne autentičnosti $u$ iskustvima turista u susretu sa stranom kulturom, potom problem susreta s Drugim u odnosu na rastuće multikulturne strukture u korejskom društvu i interkulturne susrete u njihovom društvenom aspektu, jednako kao i "događajnost" iskušena i učinjena vidljivom konkreativnim dijaloškim procesima u stvaranju novih umjetničkih oblika. Na temelju nekoliko studija slučaja o raznolikim oblicima očuvanja baštine - u buddhističkim hramovima (Beongwonsa i Geumseonsa), Konfucijanskoj akademiji (Sosuseowon), seulskom Centru za nematerijalnu kulturnu baštinu (Gyoyukjeonsijang) te na otvorenoj pozornici Nori Madang, namijenjenoj izvedbama glazbe i plesa uvrštenih na popis nematerijalne kulturne baštine - nastoje se pokazati ambivalentnosti i proturječja njegovanja tradicije izvan konteksta negdašnjih izvedbi, koji su nestali u procesima obnove, industrijalizacije i moderni-
\end{abstract}


zacije korejskog društva nakon japanske kolonizacije (1910-1945) i Korejskog rata (1950-1953). Proces baštinizacije, provođen od početka 1960-ih uz potporu i nadzor državne administracije, doveo je do izrazite petrifikacije i profesionalizacije tradicije te stvaranja novih, sofisticiranih i visokoumjetničkih oblika skraćena trajanja, koji se izvode u novim kontekstima, s novim značenjima i funkcijama.

Ključne riječi: nematerijalna kulturna baština, interkulturalnost, autentičnost, iskustvo, kreativna ekonomija 